\title{
VELIKI ATLAS SLOVENIJE
}

\section{Veliki atlas Slovenije. Založba Mladinska knjiga, 655 str. Ljubljana, 2012}

Po štirih izdajah Atlasa Slovenije s topografskimi kartami celotne Slovenije v merilu $1: 50.000$ in različnimi dodatki se je založba Mladinska knjiga odločila narediti velik korak naprej in izdati - Veliki atlas Slovenije. Zelo obsežno delo je lepa in vsestranska geografska predstavitev Slovenije $\mathrm{v}$ zemljevidih, besedilih, preglednicah in izbranih fotografijah, pri katerem je izdatno sodeloval tudi Oddelek za geografijo Filozofske fakultete Univerze v Ljubljani (Darko Ogrin, Dušan Plut in Irma Potočnik Slavič).

Prva izdaja Atlasa Slovenije s topografskimi kartami v merilu 1 : 50.000 je nastala v sodelovanju založbe s takratnim Geodetskim zavodom Slovenije in je izšla v nekem povsem drugem času (1985). Pomenila je izjemen preboj v uporabi podrobnih topografskih kart v vsakdanjem življenju, saj so bile dotlej tovrstne karte strogo zaupno vojaško gradivo in smo lahko navadni ljudje uporabljali le zelo stare (predvojne) jugoslovanske topografske karte. $\mathrm{V}$ današnjem času je to sicer težko razumljivo, a takšne družbene razmere in zelo kvalitetno izdelane, vsestransko uporabne topografske karte, sta bila razloga, da je delo postalo velika uspešnica - štiri izdaje atlasa (1985, 1992, 1996 in 2005) je založba prodala v skupni nakladi več kot 160.000 izvodov. Od prve izdaje do zdaj je atlas »... nedvomno odražal zahteve naše vsakdanjosti po učinkoviti izrabi časa, boljši prostorski mobilnosti in hitri orientaciji v prostoru.« (Atlas Slovenije, 4. izdaja, 2005). Zaradi velikosti atlas sicer ni bil primeren za prenašanje $\mathrm{v}$ nahrbtniku, a je odlično služil orientaciji po slovenskem prostoru doma ali v službi, načrtovanju izletov, skratka, v tistem času je (s kartografskim delom) dobro služil osnovnemu namenu, prinašal pa je tudi najrazličnejše druge informacije o naši državi.

Silovit razmah satelitske navigacije in njen prodor v avtomobile, nahrbtnike, na kolesa in mobilne telefone nam neverjetno olajša orientacijo o prostoru, vendar GPS verjetno ne bo nikoli mogel povsem nadomestiti topografske (in tematske) karte. Takšen razvoj je očitno spodbudil založbo, da je začela razmišljati o nečem drugem, kar bi sprejeli tudi današnji potencialni uporabniki - in to je brez dvoma - skoraj povsem na novo zasnovan poljudnostrokoven nacionalni atlas z najširšo paleto vsebin in informacij o naši državi. Nastalo je res obsežno, že na prvi pogled simpatično delo, ki se s svojo drugačnostjo lepo vključuje v kar lepo skladovnico geografskih del o Sloveniji, ki so izšla v dobrih 20 letih naše samostojne države. S širokim spektrom vsebin, zelo velikim naborom tematskih kart, zanimivimi besedili, tabelaričnimi prikazi, fotografijami in, seveda, z najpomembnejšim delom - 218 topografskimi kartami celotnega slovenskega ozemlja v merilu $1: 50.000$ ter zemljevidi 66 slovenskih mest v merilu $1: 12.500$ (Ljubljana v merilu $1: 20.000$ ) je lepo in uporabno delo, po katerem naj bi/bi moral čim bolj pogosto posegati najširši krog uporabnikov. Atlas bi lahko bil neposredno koristen pri načrtovanju prostega časa, bralec bi lahko iz njega izvedel veliko novega o svoji domovini. Uporabljati bi ga morali tudi vsi, ki kakor koli odločajo o 
prostoru, saj nas zlasti tematske karte zelo glasno opozarjajo, kako izjemno bogastvo je naša pokrajinska, biotska, kulturna in druga raznovrstnost in kako občutljiv je ta naš omejeni prostor, topografske karte pa, kako neodgovorno ravnamo z njim.

Slaba polovica Velikega atlasa Slovenije je povsem nova, razdeljena na sedem obsežnih poglavij. Eno od teh je 60 strani že omenjenih tematskih kart, ki predstavljajo razporeditev in značilnosti najrazličnejših geografskih in drugih pojavov. V ostalih poglavjih, ki so jih deloma napisali tudi geografi z našega oddelka, so v besedi in sliki prikazane slovenske pokrajine (Darko Ogrin), naravna in kulturna dediščina Slovenije (Darij Krajčič in Janez Bogataj), okoljski in drugi sodobni problemi (Anton Komat, Andrej Klemenc, Irma Potočnik Slavič in Darko Ogrin), predstavljeni so najrazličnejši številčni podatki o Sloveniji (poglavje Slovenija v številkah) in glavne turistične znamenitosti. V posebnem poglavju pred topografskimi kartami so še kratki, a koristni opisi vseh slovenskih občin (vključno z občinskimi grbi) ter kulturnozgodovinski orisi 65 slovenskih mest, vsako predstavljeno tudi z značilno fotografijo.

Če nam je v prvih letih samostojnosti zelo primanjkovalo geografske in druge literature o Sloveniji, smo lahko vsaj z geografsko bero dveh desetletij samostojnosti kar zadovoljni. Kaže, da se geografi zavedamo, kako je poleg 'strogo' znanstvenega raziskovanja in pedagoškega dela na vseh stopnjah izobraževanja zelo pomembno prispevati tudi k takšnim, finančno in drugače zelo zahtevnim knjižnim projektom, ki našo stroko prek prizadevanj založbe prinesejo dobesedno v vsak slovenski dom.

Karel Natek 